DOI 10.14746/ssp.2019.3.4

\author{
Jędrzej SKRZYPCZAK
}

Adam Mickiewicz University in Poznań

ORCID: 0000-0002-5906-3802

\title{
Protection of the reputation of the Polish Nation and the Republic of Poland
}

\begin{abstract}
A pretext for taking up this topic was the adoption in January 2018 of the new Act of the Institute of National Remembrance, which aroused huge controversy. In this way, provisions were enacted to protect the reputation of the Republic of Poland and the Polish Nation. Among them, there are regulations such art. 53o and 53p providing civil liability for violating the reputation of the Republic of Poland and the Polish Nation. This part of the bill passed almost unnoticed, unlike the criminal law in this bill. Certainly, a full analysis of this normative act requires more time. For now, we can say that - as it was presented in this paper - the adopted regulation raises a number of doubts and questions about its proper interpretation.
\end{abstract}

Key words: protection of the reputation of the Polish Nation and the Republic of Poland

\section{Introduction}

The issue of protecting the reputation (and possibly also other rights 1 of the individual) of the Polish Nation and the Republic of Poland arouses both theoretical and practical interest. This task can be performed using a variety of measures and legal methods. This study focuses exclusively on the protection measures ensured by civil law while ignoring other methods, in particular criminal law measures that would certainly require a separate discussion which seems to go beyond the limits of this article. Nevertheless, it should be noted that on January 17, 2019, the Constitutional Tribunal (file no. K1/18) ruled on the motion of the President of the Republic of Poland to examine the compliance with the Constitution of certain amendments to the Law on the Institute of National Remembrance, introduced in 2018. The presidential motion, however, concerned only the criminal provisions introduced.

The discussion of these issues was inspired by the adoption of the controversial (in Poland but especially abroad) Law of January 26, 2018 
amending the Law on the Institute of National Remembrance - Commission for the Prosecution of Crimes against the Polish Nation, the Law on Graves and War Cemeteries, the Law on Museums and the Law on the Liability of Collective Entities for Acts Prohibited under Penalty (Dz. U. [Journal of Laws] of 2018, item 369). By virtue of these amendments, the Law on the Institute of National Remembrance had chapter 6(c), titled "Protection of the Reputation of the Republic of Poland and Polish Nation" added. The provisions in Articles 53(o) and 53(p) pertain to liability under civil law. This amendment arouses serious doubts. Firstly, the question arises whether such protection was ensured in the former legal status quo and if so, on what legal basis. Secondly, what have the new regulations changed in this matter? Thirdly, how should the terms "Polish Nation" and "the Republic of Poland" be understood and, fourthly, who has locus standi and therefore the possibility to bring an action in such cases? Finally, how can such actions be brought with respect to foreign entities, and what effectiveness will this type of legal action have outside Poland? This study was developed using a variety of research methods, including inductive and deductive reasoning, institutional and legal analysis and exegesis of legal text.

\section{The concept of the rights of the individual}

These considerations should begin with an explanation of the concept of the rights of the individual. This is not defined by the legislator in the Polish legal system (Sadomski, 2008, p. 51). Nevertheless, the legal system provides for the protection of such legal rights by a variety of measures and regulations. Firstly, the rights of the individual are protected by the Constitution of the Republic of Poland. Article 30 of the Constitution stipulates the principle of the inviolable, inherent and inalienable dignity of a person as the source of the freedoms and rights of persons and citizens. Article 31(1) guarantees the protection of freedom of the person and Art. 41(1) - personal inviolability and freedom. Article 47 of the Constitution stipulates the following: "Everyone shall have the right to legal protection of his private and family life, of his honor and good reputation and to make decisions about his personal life." Article 49 of the Constitution guarantees freedom and privacy of communication; Art. 50 guarantees the inviolability of the home; Art. 51 stipulates the right of protection of personal information; Art. 53 guarantees freedom 
of conscience and religion and Art. 54 - freedom of speech. The latter guarantees everyone the freedom to express opinions and to acquire and to disseminate information.

There are also criminal law measures, such as defamation or insult, and insulting the Polish nation or the Polish state (Art. 133 of the Penal Code). Under civil law, Art. 23 of the Civil Code uses the category of rights of the individual without defining them and lists examples of such rights. The catalog of the rights of the individual cannot therefore be deemed closed, and the values to which legal protection is provided are not exhaustively indicated here (Sokołowski, 2012; Księżak, 2014). Pursuant to this regulation, the rights of the individual, in particular health, freedom, dignity, freedom of conscience, name or pseudonym, image, privacy of correspondence, inviolability of home, and scientific, artistic, inventive or improvement achievements are protected by civil law, independently of protection under other regulations. On the other hand, both the legal doctrine and jurisprudence of Polish courts feature numerous attempts to define the concept of the rights of the individual (PanowiczLipska, 1975, p. 23; Piątkowski, 1983, pp. 20 ff.; Cisek, 1989, pp. 35 ff., Wojciechowska, 1994, pp. 372 ff.; Sadomski 2008, pp. 53 ff.; Barta, Markiewicz, 2009, pp. 21 ff.; Czub, 2012, p. 56). One approach understands it as "the values recognized by the legal system, including the physical and mental integrity of a person, his individuality, dignity and position in society, which is the premise for the self-fulfillment of the human being" (Radwański, 2004, p. 156). In another definition, the rights of the individual are "non-proprietary values that are related to human personality, commonly recognized in society" (Szpunar, 1979, p. 106; Pazdan, 2002; Rudnicki, 1992, p. 34; Grzybowski, 1957, p. 78). There have also been attempts to define this category in jurisprudence. The resolution passed by seven judges of the Supreme Court on July 16, 1993 (file no. I PZP 28/93) stresses that "this concept should be related to a specific level of technological and civilizational development, moral and legal principles adopted in society, and to the existing type of social, economic and even political relations." The Court of Appeals in Lublin issued a ruling on April 21, 2015 (file no. I ACa 894/14), where it reiterated the legal definitions stating that "the rights of the individual are values including the physical and mental integrity of a person, his individuality, dignity and position in society, which is the premise for self-fulfillment of a human being." The above discussion implies that the category of the rights of the individual is by principle inherently related to the human being. 
Certain rights of the individual, however, are protected with respect to collective subjects. Dignity is protected by virtue of international law, including European law, as well as by the regulations in the constitution. Human dignity is referred to in this case. In the context discussed in this study, Art. 30 of the Constitution is of particular significance, which stipulates the following: "The inherent and inalienable dignity of the person shall constitute a source of freedoms and rights of persons and citizens." Article 47 of the Constitution guarantees the protection of honor and good reputation among other things. As mentioned above, one of the rights of the individual explicitly indicated in Art. 23 of the Civil Code is "honor." At present, honor is equivalent to dignity in judicature, as evidenced by the verdict passed by the Supreme Court on October 29, 1971 (file no. II CR 455/71), which claims that "honor and dignity are values all humans are entitled to" and "a person's honor, good name and reputation are concepts embracing all fields of life" (Sobczak, 2006, p. 9). There are legal opinions where human dignity is divided into external - good reputation, and internal - personal dignity (Szpunar, 1979, p. 129). Typically, it is assumed that in colloquial speech, dignity will mean respect, reverence, recognition, honor, good reputation and personal dignity (ruling of June 2, 2009, SK 31/08, OTK-A 2009, no. 6, item 83, ruling of the Constitutional Tribunal of October 30, 2006, P 10/06, OTK-A 2006, no. 9, item 128, ruling of the Constitutional Tribunal of September 29, 2008, SK 52/05 OTK-A 2008, no. 7, item 125). The view presented in legal doctrine that the protection of honor embraces all fields of human activity, namely personal, professional and social life, should be agreed with. The ruling passed by the Supreme Court on April 25, 1989 (file no. I CR 143/89) argues that "personal dignity is this part of personality which focuses on the person's feeling of his own value and the expectation of respect from other persons. This feeling forms a significant part of the human psyche and is formed by numerous different external factors. It is not permanent. As a product of the development of human nature, it is conditioned by history and culture. The assessment of whether human dignity has been violated or not is based on objective criteria rather than on a subjective feeling of the person demanding to be legally protected. The measure allowing the assessment of whether a person's dignity has been violated or not should be sought in public opinion." Another important ruling was passed by the Constitutional Tribunal on February 7, 2005 (file no. Sk 49/03, OTK A 2005 , no. 2, item 13), which stressed that no regulation justifies the claim that dignity has to be protected solely in proprietary terms. On the contra- 
ry, the manner of protecting human dignity has to be associated with the moral standards of a given society. It is well-established social beliefs that imply how a moral harm should be removed and repaired. The dignity of a human person always requires courts of justice and other public authorities to ensure that every moral harm will be removed and repaired as far as possible. Another opinion deserving support is that a breach of reputation may "consist of falsely accusing a person of such behavior or characteristics that may humiliate the person in public opinion or expose them to the loss of confidence needed for a given position, occupation or type of activity. This may involve both the dissemination of a specific content that constitutes an allegation against the individual, and the expression of a negative assessment of their activity" (Wierciński, 2002, p. 60).

The rights of the individual are typically classified in civil law doctrine as so-called absolute subjective rights, effective erga omnes (Barta, Markiewicz, 2005, p. 21). Due to being inherently related to the human person, the rights of the individual are inalienable, non-transferable via inter vivos, and cannot be inherited. Consequently, only the aggrieved party can demand (has a locus standi) protection of the rights of the individual. Importantly, non-pecuniary claims formulated on this basis are not subject to the statute of limitations (Piasecki, 2003). Another dominating opinion is that the concept of the rights of the individual is objective rather than subjective. This means that "both when explaining the nature of the rights of the individual and that of their violation an objective criterion should be applied which refers to assessments by society" (Pazdan, 2012).

\section{Protection of the rights of the individual for legal persons}

The current legal system guarantees a certain extent of protection of the rights of the individual for legal persons, too (Cisek, 1989; Koczanowski, 1990, pp. 17-30; Kubiak-Cyrul, 2005; Matys, 2006; Michałowska, 2015, pp. 7-18). This is of significance, since the same principles can apparently apply to such collective entities as nations, among others. It should therefore be remembered that, pursuant to Art. 33 of the Civil Code, legal persons include the State Treasury and organizational units which are attributed legal personality under specific laws. Pursuant to Art. 43 of the Civil Code, in turn, the provisions on the protection of the rights of the individual for natural persons apply to legal persons, too. The ruling of the Supreme Court passed on November 14, 1986 (file no. II CR 295/86) stresses that "the 
rights of the individual for legal persons are non-proprietary values thanks to which a legal person can operate within the scope of its activities." The ruling of the Supreme Court passed on May 25, 1977 (file no. I CR 159/77), indicates that "pursuant to Art. 43 of the Civil Code, the provisions on the protection of the rights of the individual for natural persons apply to legal persons [...] However, the accurate application of Art. 23 of the Civil Code excludes from protection such rights of the individual as [...] image, which cannot be taken into consideration in the case of legal persons." In this context, particular attention should be given to the ruling by the Court of Appeals in Białystok, passed on November 6, 2015 (file no. I ACa 585/15), which puts forward a thesis that the protection of the rights of the individual for legal persons pertains to their rights associated with their operations and ensuring their uninterrupted functioning, in particular such rights as their name (company), trademark, commercial reputation and privacy of correspondence. The rights of the individual for legal persons also include good reputation, brand, renown and well-established position. The rights of the individual related to the sphere of feelings, such as dignity, have been excluded from attribution to legal persons. The protection of the rights of the individual for legal persons depends solely on an objectively determined infringement of their rights of the individual by an unlawful act (Skrzypczak, 2017, pp. 137 ff.).

It is, however, doubtful whether the State Treasury is entitled to the protection of the rights of the individual arising from damage to the reputation of the Republic of Poland or the Polish Nation. It seems, therefore, that the justification of the above-mentioned Law on the Institute of National Remembrance rightly states that, in the current legal status quo, the concept of bringing claims for damages (for the repair of a pecuniary damage) against entities using damaging language arouses doubts, as it is impossible to indicate damages to state property, while making claims under civil law on the basis of the protection of the rights of the individual is also considerably questionable in Polish law.

\section{Protection of the rights of the individual for determined communities}

As indicated above, it is considerably more complicated to assess whether determined communities that are not granted the status of legal persons under current law, such as nations, have the possibility of deman- 
ding that their rights of the individual be protected (Skrzypczak, 2017, pp. 144 ff.). In the understanding of civil law, such groups are not a separate subject of law. They can be granted protection under separate regulations. Pursuant to Art. 4(1) of the Polish Constitution, "Supreme power in the Republic of Poland shall be vested in the Nation." This provision inspires different interpretations of how to define this notion, i.e. who can qualify as a nation. The prevailing opinion is that "the case concerned regards all citizens of the Polish Republic (as defined in the Preamble), which means that membership of the nation understood in this manner is based on holding Polish citizenship. We are dealing with the Nation in the legal and political rather than ethnic terms. Who is part of the Nation is decided by the principles of citizenship" (Skrzydło, 2013, p. 235). Additionally, pursuant to Art. 1 of the Constitution, "The Republic of Poland shall be the common good of all its citizens" while Art. 82 stipulates that "[1]oyalty to the Republic of Poland, as well as concern for the common good, shall be the duty of every Polish citizen." Article 85(1) makes it the duty of every Polish citizen to defend the homeland.

\section{Protection of the reputation of the Republic of Poland and the Polish Nation}

Before the amendments were introduced, the protection of the reputation of the Polish Nation was exercised on the basis of the legal status quo discussed above. The ruling of the Supreme Court issued on December 12, 1978 (file no. IV CR 421/78) stated that the publication of unverified information about incidents of collaboration with the Germans during the occupation was not only unlawful, but also harmful. The issue of the unlawfulness of the defendant was the more serious, as he was a historian and collaborator with the Commission for the Investigation of Nazi Crimes in Poland. While it is in the social interest to reveal all acts of collaboration with the Nazi occupiers, it is also in the interest of the entire Nation for the facts from its modern history, including the difficult period of the occupation, to be presented truthfully. The following rulings clearly set a precedent: the ruling passed by the District Court in Olsztyn on February 24, 2015 (file no. I C 726/13), the ruling passed by the Court of Appeals in Krakow on December 22, 2016 (file no. I ACa 1080/16), the ruling passed by the Court of Appeals in Warsaw on March 31, 2016 (file no. I ACa 971/15), which stipulated that the national heritage, legacy, 
identification with the achievements and values represented by ancestors is a right of the individual protected by virtue of Art. 23 and Art. 24 of the Civil Code. The continuation and cultivation of ancestors' traditions is recognized as a significant value, also taking into account objective criteria. In the justification to the verdict, it was said that in order to recognize the violation of the sense of national identity by speaking about Polish concentration camps it is not necessary for this statement to indicate a concrete person who is a member of the Polish nation. Uttering such a statement directly damages the values related to individual participation in a community which naturally shapes this individual's personality. It enters the realm of values forming the foundation of the protection of honor understood as personal dignity, because it refers to the continuation associated with participation in the Polish national community, being the same and maintaining continuity. The justification of the verdict issued by the court indicated that the current existence of the national community is an extension of its existence in the past. Importantly, it stressed the fact that speaking about Polish concentration camps violated the plaintiff's right to identify with the nation which had experienced the atrocity of concentration camps and whose ancestors (grandparents) had been persecuted in concentration camps. The historical events which constitute the legacy of remembrance of the community and its individual members, have an unprecedented character and are considered as an indisputable fact, cannot be relativized because they undermine the feeling of national belonging and create a sense of wrong, creating a grossly false image of Poland among the public, and attributing to Poles features that strip them of dignity and undermine their sense of value. The right of feeling national identity is rooted in Article 8 of the European Convention for the Protection of Human Rights and Fundamental Freedoms. The justification to the ruling stressed the fact that speaking about Polish concentration camps is an ambiguous presentation of facts, which could mislead hearers, some of whom might interpret this as information about the participation of the Polish nation in establishing concentration camps or in the crimes committed in them, while it is a journalist's task to avoid the dissemination of such fragmentary information which creates a risk of misleading people. In the opinion of the court, it could not be assumed that this was a case of a mental shortcut allowed by the law. The dissemination of such phrases is against the law and has resulted in a violation of the plaintiff's rights of the individual in the form of the sense of national identity and national dignity. Importantly, the Court of Appeals decided that the plaintiff had 
a locus standi in this case. The defendant's statements entered the realm of non-proprietary values associated with the plaintiff's personality. This means that the claim to protect the feeling of national dignity can be submitted not by the State Treasury as a separate legal person, or by any other government body or institution, but by an individual, a natural person who identifies with the Polish Nation.

\section{Protection of the reputation of the Republic of Poland and the Polish Nation in light of the amendment to the Law on the Institute of National Remembrance}

Controversy has clearly been aroused by the aforementioned Law of January 26, 2018 amending the Law on the Institute of National Remembrance - Commission for the Prosecution of Crimes against the Polish Nation, the Law on Graves and War Cemeteries, the Law on Museums and the Law on the Liability of Collective Entities for Acts Prohibited under Penalty (Dz. U. [Journal of Laws] of 2018, item 369). The authors of the justification for the draft (Druk sejmowy [Parliamentary print] no. 806) supported the need to introduce such legal solutions, on the one hand referring to the attitude presented by the Constitutional Tribunal in its ruling of October 30, 2006 (file no. P 10/06), that in light of Art. 31(3) of the Constitution of the Republic of Poland there is no ground to attribute priority to the protection of freedom of speech over other constitutional freedoms and rights; on the other hand, the Tribunal made reference to the judgement delivered by the European Court of Human Rights on October 15, 2015 in the case of Perinçek v. Switzerland (Application no. 27510/08), which confirmed that the dignity of the victims and the feeling of identity of contemporary Armenians can be protected under Article 8 of the Convention (right to respect for private life) and can be deemed to be a justified goal of intervention in the understanding of Art. 10(2) of the Convention.

As regards the protection ensured by civil law, the justification of the draft stressed that "the provisions stipulating the rules for pursuing claims arising from the violation of the reputation of the Republic of Poland and the Polish Nation, proposed in the new chapter 6(c) of the Law on the Institute of National Remembrance constitute a significant systemic novelty. In this regard, it is proposed to refer to the provisions of the Civil Code on the protection of the rights of the individual." By virtue of this normative 
act, chapter 6(c) entitled Protection of the reputation of the Republic of Poland and the Polish Nation was introduced to the legal order. Article 53(o) explicitly provides that, for the protection of the reputation of the Republic of Poland and the Polish Nation, the relevant provisions of the Civil Code on the protection of the rights of the individual apply. This regulation implies that the Polish Nation and the Republic of Poland are entitled to protection of their reputation. Additionally, the authors of the draft explain that as regards the legal regulations pertaining to the terms "Republic of Poland" and "Polish Nation," pursuant to the Preamble to the Constitution of the Republic of Poland, the "Polish Nation" means all the citizens of the Republic of Poland, while "Republic of Poland" is the name of the Polish state which is the common good of all its citizens pursuant to Art. 1 of the Polish Constitution. In the opinion of the authors of the justification for the amendment, the regulations proposed attributing analogous rights of the individual to the Republic of Poland and the Polish Nation as to legal persons. This conclusion, however, is questionable and the legislature should be criticized for failing to make a clear decision to this effect in the law concerned. While the concept of the Republic of Poland, defined as a common good of all citizens, is important, it nevertheless refers to the state, and thus cannot be considered as a subject.

The legal opinions on the amendment concerned criticized it because "the rights of the individual can be attributed solely to persons who can be subjects of civil law relationships. Neither the Republic of Poland nor the Polish Nation is such a subject. The formulation of the law cannot be justified by saying that the provisions on the protection of the rights of the individual will be applied 'accordingly.' In other words, civil law cannot be extended to embrace civil law relationships in which certain entities cannot participate. This may result in a lawsuit being rejected pursuant to Art. 199(1)(3) of the Code of Civil Procedure, due to one of the parties lacking legal capacity. These circumstances are not changed by the fact that the action to protect the reputation of the Republic of Poland or the Polish Nation can be filed by a non-governmental organization under its statutory responsibilities or by the Institute of National Remembrance. Organizations are not the subjects of proceedings, but act for the benefit of the party with legal capacity. Thus the Law does not include an explicit provision that the Republic of Poland and the Polish Nation are attributed with the rights of the individual in the understanding of the Civil Code, nor that the Republic of Poland and the Polish Nation are treated as subjects with legal capacity. It is also not stated that the cases for the protec- 
tion of the rights of the individual for the Republic of Poland and the Polish Nation are treated as civil cases to which the provisions of the Civil Code and the Code of Civil Procedure apply and, when need arises, these provisions are applied accordingly" (Wyrembak after Guzik, 2018).

Another doubt that needs to be considered concerns the question of whether the principles developed with respect to the protection of the rights of the individual for legal persons should be applied to the Republic of Poland and the Polish Nation. It is not easy to answer this question. On the one hand, the catalog of the rights of the individual subject to protection in such cases will be even more restricted, coming down solely to the protection of good reputation. On the other hand, this concept is likely to be treated more widely and cannot be reduced to the synonyms of good reputation, renown and well-established position, as is the case of legal persons. It is beyond doubt that the protection of legal persons demanding the protection of the rights of the individual associated with the realm of feelings, such as dignity, is excluded; however, this it is not the case with the categories examined here. In this case it is possible to indicate and refer to the realm of feelings shared by members of the community, in this event - the feeling of national dignity. This conclusion cannot, however, defy the general idea that the protection of the rights of the individual for legal persons depends solely on an objectively determined infringement of their rights of the individual by an unlawful act.

As regards the above-quoted provision in the Law on the Institute of National Remembrance that stipulates that the relevant regulations of the Civil Code should be applied, it should be assumed that the reasons for implementing such civil liability are identical to those indicated in Art. 24 of the Civil Code. These reasons include, firstly, the existence of a specific right of the individual (in this case, reputation); secondly, the fact that such a right is in threatened or subject to breach and, thirdly, the unlawfulness (the ruling passed by the Court of Appeals in Łódź on December 17, 2015, file no. I ACa 806/15) of such threat or breach. The concept of the rights of the individual has been discussed above, so it will be ignored here, whereas attention needs to be given to further reasons determined in Art. 24 of the Civil Code. Legal doctrine, as well as jurisprudence, rightfully indicate that "the concept of the protection of the rights of the individual is based on the presumption of the unlawfulness of the activity which interfered in the field covered by the protection of the rights of the individual" (Barta, Markiewicz, 2005, p. 25). This approach results in the burden to provide evidence being transferred to the person infringing on any of the values protected by 
virtue of these regulations. In other words, it is the defendant who is required to evidence that their behavior was not unlawful. Unlawful behavior is deemed to be inconsistent with legal norms or the principles of social coexistence. It is rightfully claimed in legal doctrine that the interpretation of the above cannot be broadened, and it cannot mean that the transmitted content is presumed to be false. The general principles of the distribution of the burden of evidence apply in this regard (Barta, Markiewicz, 2005, p. 25). Similarly, it is stressed in the ruling passed by the Supreme Court on June 4, 2003 (file no. I CKN 480/01) that "Art. 25 of the Civil Code includes $[\ldots]$ the presumption of the unlawful activity of the perpetrator of the breach of the rights of the individual, which is why the obligation to evidence that this activity was not unlawful burdens the perpetrator. In conformity with the objective concept of unlawfulness applied in the Polish law, unlawful behavior is behavior contrary to legal regulations or the principles of social coexistence, and unlawfulness excludes activities based on legal regulations, compliant with the principles of social coexistence, acting with the consent of the aggrieved party or exercise of subjective law." A similar standpoint is expressed in a more recent ruling passed by the Court of Appeals in Białystok on May 7, 2015 (file no. I ACa 703/14), and stating that "such protection is ensured to prevent an unlawful breach of a right of the individual, understood as behavior contrary to the norms of law or principles of social coexistence, regardless of the perpetrator's guilt or even awareness." The catalog of circumstances in which the unlawfulness of the breach of the rights of the individual is excluded justifiably includes "activities within the framework of the legal order, namely activities permitted by the legal regulations in force, exercising of subjective law, the consent of the aggrieved party (although with certain reservations) and acting to protect a justifiable interest" (Piasecki, 2003, thesis 4). The ruling passed by the Supreme Court on April 7, 2009 (file no. I PK 210/08) states that "the unlawfulness of the perpetrator's actions alone is not sufficient for the claims referred to in Art. 24 of the Civil Code to arise. A result of the perpetrator's action is necessary, such as the infringement of one of the rights stipulated in Art. 23 of the Civil Code." Importantly, "to some extent, a majority of laws exclude the unlawfulness of the breach of a certain right of the individual" (Księżak, 2014). Working to protect the rights of the individual for natural and legal persons, courts have developed a consistent line of rulings whereby (ruling passed by the Court of Appeals in Katowice on April 30, 2015, file no. I ACa 1093/14, LEX nr 1740628) "whether or not a right of the individual has been violated due to someone's behavior is 
determined by an objective criterion, such as the perception of this behavior by a reasonable, impartial listener who is not emotionally involved, and the subjective reception of the person who considers themselves an aggrieved party is of no significance (ruling passed by the Court of Appeals in Warsaw on May 18, 2016, file no. VI ACa 612/15 LEX nr 2076725). It appears that this concept will also apply to the protection of the reputation of the Republic of Poland and the Polish Nation.

It was also justifiably postulated in legal doctrine that "it is not justified to restrict the circle of entities that can file a claim for the protection of the above-mentioned rights only to former prisoners of German concentration and death camps or to their relatives and, additionally, it is not necessary to include an indication of the plaintiff in the contents of the message in order to bring an action" (Rakiewicz, 2009, p. 39; Guzik, 2018).

The above-quoted regulation stipulates that an action for the protection of the reputation of the Republic of Poland and the Polish Nation can be brought by a non-governmental organization within the framework of its statutory tasks (Guzik, 2018). Pursuant to Art. 3(2) of the Law of April 24, 2003 on Public Benefit and Volunteer Work (Dz. U. [Journal of Laws] of 2016, item 1817), non-governmental organizations are, firstly, entities which do not form part of the public finance sector and which are not enterprises, research institutes, banks or commercial law corporations that are the legal persons of central or local governments; and, secondly, entities which do not operate for profit - corporate and non-corporate entities, which according to separate legal provisions have the capacity to perform acts in law, such as foundations and associations. Thus, only social organizations that meet the above criteria will have the locus standi to file such claims. However, there is an additional requirement here, namely the matter of protecting the reputation of the Republic of Poland and the Polish Nation has to be included among the statutory tasks of such organizations. Additionally, pursuant to Art. 53(p) of this Law, this is also a prerogative of the Institute of National Remembrance, which has legal capacity in such cases. Whereas the wording of Art. 53(p) does not explicitly stipulate such a possibility, given the verdicts passed so far, it cannot be ruled out that such an action can be brought by a natural person who identifies with the Polish Nation.

By virtue of the above regulation, it is stipulated that redress or compensation will be due to the State Treasury. This is not, however, the exhaustive catalog of claims provided for in the Civil Code. Pursuant to Art. 24(1) of the Civil Code, the person whose right of the individual is threatened by someone else's action, can demand that this action be abandoned, unless it 
is not unlawful. In the event of infringement, he may also demand that the person who has committed the infringement take the actions necessary to remove its consequences, in particular submit a statement of appropriate content and in an appropriate form. It results from the above that in the case of a threat to the rights of the individual, one is entitled to demand such an activity to be abandoned. In the event of a breach having taken place, the plaintiff is entitled not only to demand for such activities to be abandoned, but also for the person who committed the infringement to take the actions necessary to remove its consequences, such as submitting a statement of appropriate content and in an appropriate form. This does not preclude the possibility of seeking redress under the terms of Art. 448 of the Civil Code. Pursuant to Art. 24(2) of the Civil Code, whereby if proprietary damage occurred due to the infringement of a right of the individual, the aggrieved party can demand its reparation on general terms. A doubt arises here, then, whether a non-governmental institution or the Institute of National Remembrance demanding the protection of the tarnished reputation of the Republic of Poland or the Polish Nation are entitled only to receive redress, compensation, or all the above. The latter option seems accurate.

Additionally, the Law on the Institute of National Remembrance stipulates that the above provisions will apply regardless of which law is applicable. It is stressed in the justification to the Law that "international jurisdiction in such cases will be determined primarily in conformity with Regulation (EU) No 1215/2012 of the European Parliament and of the Council of 12 December 2012 on jurisdiction and the recognition and enforcement of judgments in civil and commercial matters (and in the event where an entity infringing the reputation of the Republic of Poland or the Polish Nation is not domiciled in any EU state - according to the regulations of the Code of Civil Procedure). This means that Polish courts will be competent to try such cases either when - pursuant to a general provision (Art. 4(1) of the Regulation) - the defendant (the infringing party) is domiciled in the Republic of Poland or when - pursuant to the provisions on special jurisdiction in matters of prohibited acts (Art. 7(2) of the Regulation) - 'the harmful event occurred' in the Republic of Poland (e.g. in the event of media torts - when information harmful to the reputation of the Republic of Poland or the Polish Nation is disseminated also in the Republic of Poland and produces negative outcomes there)." Additionally, the justification to the Law explains that, as concerns the principles determining which law is applicable to the protection of the rights of the individual (as indicated in the draft regulations on the protection of the 
reputation of the Republic of Poland or the Polish Nation), in principle, they are stipulated in the Law of February 4, 2011 on Private International Law (Dz. U. [Journal of Laws] item 432, as amended). It is also noted that these matters are excluded from the scope to which Regulation (EC) No 864/2007 of the European Parliament and of the Council of 11 July 2007 on the law applicable to non-contractual obligations (Rome II) applies, on the basis of Art. 1(2)(g) of this Regulation.

Pursuant to the provisions of the Law on Private International Law (Art. 16(2) and Art. 20), in the event of infringement or threat that a right of the individual may be infringed, protection can be demanded on the basis of either the law of the state where an event resulting in such infringement or threat of infringement occurred, or the law of the state where the results of such infringement occurred. Therefore, in order to ensure that the Polish provisions on the protection of the reputation of the Republic of Poland or the Polish Nation apply in every case, irrespective of what law is applicable in light of the Law on Private International Law, an additional provision is proposed (new Art. 53(r) in the Law on the Institute of National Remembrance) which will unambiguously indicate that these are overriding mandatory regulations (cf. Art. 8(1) of the Law on Private International Law).

\section{Conclusions}

In the prior legal framework, attempts were made, quite successfully, to protect the reputation of the Polish Nation based on Art. 23 of the Civil Code. The amendment examined in this article raises numerous doubts and questions about its appropriate interpretation. It practically ignores rulings passed by courts using the prior legal framework and allows members of a specific group, e.g. the Polish Nation, to pursue claims in an event of a violation of the feeling of national dignity. The domestic, but primarily international criticism of the amendment to the Law and the Institute of National Remembrance first and foremost pertained to the regulations stipulating penal measures. In the context of freedom of speech, less controversy was aroused by the above-discussed civil law solutions enabling a response to such acts. The above analysis has attempted to demonstrate, however, that even those solutions are not faultless and need to be approached critically. Taking into account the history of judicial decisions, questions about the purpose of introducing new solutions should be asked, as similar, or even further-reaching results could have been achieved under the previous law. 
In the amendment, the "Polish Nation" is defined pursuant to the Preamble to the Constitution of the Republic of Poland as all the citizens of the Republic of Poland, while "Republic of Poland" is the name of the Polish state which, according to Art. 1 of the Constitution is a common good of all its citizens. Art. 53(o) of the Law explicitly stipulates that, for the protection of the reputation of the Republic of Poland and Polish Nation, the relevant provisions of the Civil Code on the protection of the rights of the individual apply. An action to protect the reputation of the Republic of Poland or the Polish Nation can be brought by a non-governmental organization under its statutory responsibilities. Additionally, in conformity with Art. 53(p) of the Law, the Institute of National Remembrance also has the same prerogatives. However, the Law stipulates that redress or compensation will be due to the State Treasury. Although the Law includes provisions on the jurisdiction of Polish courts, seeking redress, and even more so the execution of compensation is problematic. A question therefore arises whether such legal solutions are justified. Paradoxically, non-legal measures and methods, such as education, promotion or social pressure, can turn out to be more effective than imposing legal sanctions, including civil law.

\section{Bibliography}

Barta J., Markiewicz R. (2002), Wokót prawa do wizerunku, "ZNUJ PWiOWI", vol. 80, Kraków.

Barta J., Markiewicz R. (2009), Media a dobra osobiste, Warszawa.

Błeszyński J. (1988), Prawo autorskie, Warszawa.

Cisek A. (1989), Dobra osobiste i ich niemajątkowa ochrona w kodeksie cywilnym, Wrocław.

Czub K. (2012), O konstrukcji intelektualnych dóbr osobistych, Zeszyty Naukowe UJ no. 115.

Garlicki L., Zubik M. (eds.) (2016), Konstytucja Rzeczypospolitej Polskiej. Komentarz, vol. I, $2^{\text {nd }}$ issue, Wyd. Sejmowe.

Grzeszak T. (2017), in: System prawa prywatnego, vol. 13: Prawo autorskie, ed. J. Barta, Warszawa, $2^{\text {nd }}$ issue, pp. 539-540.

Grzybowski S. (1957), Ochrona dóbr osobistych wg przepisów ogólnych prawa cywilnego, Warszawa.

Guzik R. (2018), Komentarz do ustawy o Instytucie Pamięci Narodowej - w zakresie zmian wprowadzonych ustawami z dnia 26 stycznia $2018 \mathrm{r}$. oraz z dnia 27 czerwca $2018 r$., LEX/el. 
Haczkowska M. (ed.) (2014), Konstytucja Rzeczypospolitej Polskiej. Komentarz, LexisNexis.

Kluza J. (2016), Projektowany art. 55a ustawy o Instytucie Pamięci Narodowej (analiza krytyczna), “Cz.PKiNP”, no. 3.

Koczanowski J. (1990), Osoby prawne zależne i ich dobra osobiste, Zeszyty Naukowe Akademii Ekonomicznej w Krakowie, no. 325.

Księżak P. (2014), in: Kodeks cywilny. Komentarz. Część ogólna, P. Księżak, M. Pyziak-Szafnicka (eds.), B. Giesen, W. J. Katner, B. Lewaszkiewicz-Petrykowska, R. Majda, E. Michniewicz-Broda, T. Pajor, U. Promińska, W. Robaczyński, M. Serwach, Z. Świderski, M. Wojewoda, Lex.

Kubiak-Cyrul A. (2005), Dobra osobiste osób prawnych, Kraków.

Lis W. (2013), Publikacja listu gończego a ochrona prawa do wizerunku, "Przegląd Sądowy", no. 3.

Matys J. (2006), Dobra osobiste osób prawnych i ich niemajątkowa ochrona, "Monitor Prawniczy", no. 10.

Michałowska K. (2015), Dobre imię osoby prawnej w świetle orzecznictwa, "Studia Oeconomica Posnaniensia", vol. 3, no. 3.

Panowicz-Lipska J. (1975), Majątkowa ochrona dóbr osobistych, Warszawa.

Pazdan M. (2012), Ochrona dóbr osobistych, in: Prawo cywilne-część ogólna. System Prawa Prywatnego, ed. M. Safjan, vol. I, Warszawa.

Piasecki K. (2003), Komentarz do art. 23 kodeksu cywilnego, in: Kodeks cywilny. Księga pierwsza. Część ogólna, ed. K. Piasecki, Warszawa.

Piątkowski J. S. (1983), Ewolucja ochrony dóbr osobistych, in: Tendencje rozwoju prawa cywilnego, ed. E. Łętowska, Wrocław.

Radwański Z. (2004), Prawo cywilne. Część ogólna, Warszawa.

Rakiewicz F. (2009), Dotychczasowy stan orzecznictwa sadowego i doktryny w zakresie roszczén przeciwko zagranicznym środkom masowego przekazu o ochrone dóbr osobistych w związku z rozpowszechnianiem określeń „polski obóz koncentracyjny”, ,polski obóz zagłady” oraz podobnych sformułowań, in: Prawda historyczna a odpowiedzialność prawna. Rozważania na gruncie zniekształcania pamięci niemieckich zbrodniach popetnionych podczas II wojny światowej. Materiaty pokonferencyjne, eds. M. Berent, A. Radwan, S. Topa, Kraków.

Sadomski J. (2008), Konflikt zasad-ochrona dóbr osobistych a wolność prasy, Warszawa.

Sadomski J. (2011), Konstytucyjne źródła ochrony czci, in: Stosowanie prawa. Księga jubileuszowa z okazji XX-lecia Instytutu Wymiaru Sprawiedliwości, ed. A. Siemaszko.

Sieńczyło-Chlabicz J. (2003), Przedmiot, podmiot i charakter prawa do wizerunku, "Przegląd Ustawodawstwa Gospodarczego", no. 8.

Skrzydło W. (2013), Konstytucja Rzeczypospolitej Polskiej. Komentarz, Lex. 
Skrzypczak J. (2017), Reakcja na krytykę prasowa. Ochrona dóbr osobistych w erze nowych mediów, Poznań.

Sobczak J. (2006), Godność człowieka i pacjenta, in: Polska polityka zdrowotna a akcesja Rzeczpospolitej do Unii Europejskiej, eds. T. Maksymiuk, J. Skrzypczak, Poznań.

Sokołowski T. (2012), Komentarz do art. 23 k.c., in: Kodeks cywilny. Komentarz, vol. I: Część ogólna, A. Kidyba (ed.), Z. Gawlik, A. Janiak, A. Jedliński, K. Kopaczyńska-Pieczniak, E. Niezbecka, T. Sokołowski,Warszawa.

Stefaniuk K. (1970), Naruszenie prawa do wizerunku przez rozpowszechnianie podobizny, "Państwo i Prawo", no. 1.

Szpunar A. (1979), Ochrona dóbr osobistych, Warszawa.

Ślęzak P. (2009), Ochrona prawa do wizerunku, Katowice.

Wierciński J. (2002), Niemajątkowa ochrona czci, Warszawa.

Wojciechowska A. (1994), Czy autorskie dobra osobiste sa dobrami osobistymi prawa cywilnego, "Kwartalnik Prawa Prywatnego", no. 3.

Wojnicka E. (1990), Prawo do wizerunku w ustawodawstwie polskim, "ZNUJ, PWiOWI", vol. 56, Kraków.

\section{Ochrona dobrego imienia Narodu Polskiego i Rzeczypospolitej Polskiej}

\section{Streszczenie}

Pretekstem do podjęcia tej problematyki ochrony dobrego imienia Narodu Polskiego i Rzeczypospolitej Polskiej było uchwalenie w styczniu 2018 r. wzbudzającej ogromne kontrowersje ustawy o zmianie ustawy o Instytucie Pamięci Narodowej. W ten sposób wprowadzono przepisy przewidujące ochronę dobrego imienia Rzeczypospolitej Polskiej i Narodu Polskiego. Pośród nich zaproponowano przepisy art. 53o i 53p przewidujące odpowiedzialność cywilnoprawną. Ten fragment ustawy przeszedł właściwie niezauważony, inaczej niż wzbudzające ogromne emocje przepisy przewidujące odpowiedzialność karną. Z pewnością pełna analiza tego aktu normatywnego wymaga znacznie dłuższego czasu. Jak wyżej próbowano wykazać, przyjęta regulacja rodzi szereg wątpliwości i pytań o jej właściwą wykładnię. Pomija w zasadzie całkowicie dorobek judykatury, który w poprzednim stanie prawnym pozwalał członkowi określonej grupy np. Narodu Polskiego dochodzenia roszczeń w przypadku naruszenia poczucia godności narodowej.

Słowa kluczowe: ochrona dobrego imienia Narodu Polskiego i Rzeczypospolitej Polskiej 